\title{
Pathogenic Variation of Phakopsora pachyrhizi Isolates on Soybean in the United States from 2006 to 2009
}

M. Twizeyimana, Department of Crop Sciences, and G. L. Hartman, United States Department of Agriculture-Agricultural Research Service and Department of Crop Sciences, University of Illinois, Urbana 61801

\begin{abstract}
Twizeyimana, M., and Hartman, G. L. 2012. Pathogenic variation of Phakopsora pachyrhizi isolates on soybean in the United States from 2006 to 2009. Plant Dis. 96:75-81.

The introduction of Phakopsora pachyrhizi, the cause of soybean rust, into the United States is a classic case of a pathogen introduction that became established in a new geographical region overwintering on a perennial host (kudzu, Pueraria lobata). The objective of our study was to classify the pathogenic variation of P. pachyrhizi isolates collected in the United States, and to determine the spatial and temporal associations. In total, 72 isolates of $P$. pachyrhizi collected from infected kudzu and soybean leaves in the United States were purified, then established and increased on detached soybean leaves. These isolates were tested for virulence and aggressiveness on a differential set of soybean genotypes that included six genotypes with known resistance genes (Rpp), one resistant genotype without any known characterized resistance gene, and a susceptible genotype. Three pathotypes

were identified among the 72 U.S. $P$. pachyrhizi isolates based on the virulence of these isolates on the genotypes in the differential set. Six aggressiveness groups were established based on sporulating-uredinia production recorded for each isolate on each soybean genotype. All three pathotypes and all six aggressiveness groups were found in isolates collected from the southern region and from both hosts (kudzu or soybean) in 2008. Shannon's index based on the number of pathotypes indicated that isolates from the South region were more diverse $(H=$ 0.83 ) compared with the isolates collected in other regions. This study establishes a baseline of pathogenic variation of $P$. pachyrhizi in the United States that can be further compared with variation reported in other regions of the world and in future studies that monitor P. pachyrhizi virulence in association to deployment of rust resistance genes.
\end{abstract}

Soybean rust, caused by the obligate fungal pathogen Phakopsora pachyrhizi Syd. \& P. Syd., is one of the most damaging diseases of soybean (Glycine max (L.) Merr.) in many areas of the world. The disease was first reported in the continental United States in Louisiana in 2004 (28). The overwintering of P. pachyrhizi on kudzu (Pueraria lobata (Willd.) Ohwi) in the southern United States along the Gulf of Mexico (21) provides for sources of inoculum to initiate infection of the U.S. soybean crop each year as the pathogen spreads from the southern to the northern United States growing regions (35). Pathogenic diversity has been reported for only a few isolates of Phakopsora pachyrhizi collected from the continental United States $(1,23,25)$; however, physiological races or pathotypes among the U.S. P. pachyrhizi population have not been reported.

Many terms have been used to describe pathogen variability, including races, virulence types, pathotypes, and aggressiveness. A physiological race has been defined as a population in which all individuals carry the same combination of virulence genes (22). Virulence among other definitions has been defined as "the genetic ability of a pathogen race to overcome genetically determined host resistance, which is effective against other races of that pathogen, and cause a compatible (disease) interaction" (29). Pathotypes have been used to classify pathogen genotypes whose members express

Corresponding author: G. L. Hartman, E-mail: ghartman@illinois.edu

Trade and manufacturers' names are necessary to report factually on available data; however, the United States Department of Agriculture (USDA) neither guarantees nor warrants the standard of the product, and the use of the name by USDA implies no approval of the product to the exclusion of others that may also be suitable.

Accepted for publication 16 August 2011

http://dx.doi.org/10.1094/PDIS-05-11-0379

This article is in the public domain and not copyrightable. It may be freely reprinted with customary crediting of the source. The American Phytopathological Society, 2012. the same pattern of host-specific virulence toward individual clones or species within a specified set (26). Aggressiveness is quantitative and assessed by the degree of host damage or pathogen multiplication (29).

Pathogenic variation in P. pachyrhizi was first reported in 1966 (17) when isolates collected from Taiwan produced different lesion types on soybean and other legume hosts. In 1977, two physiological races were identified in Australian isolates based on one but not the other isolate causing rust on an identified resistance source (19). In the 1980s, there were reports of four physiological races from four isolates obtained from Australia, India, Puerto Rico, and Taiwan (4); three races from 50 Taiwanese isolates (38); six races from eight Australian isolates $(5,6)$; and four races identified from seven Chinese isolates (31). Since 2000, 18 races were identified from 45 isolates collected from Japan (37) and six pathotypes were established from 12 isolates obtained from Africa, Asia, South America, Hawaii, and Puerto Rico (1). In addition, there were eight pathotypes identified from 10 isolates from Asia, Africa, South America, and the continental United States (25) and seven pathotypes identified from 116 Nigerian isolates (34).

The races and pathotypes identified in $P$. pachyrhizi are associated with specific resistance genes in soybean identified as Rppl to $-5(3,7,13,14,19)$. Based on these studies, the resistant reaction was characterized by either an immune reaction or red-brown (RB) lesions without or with sparsely sporulating uredinia, while a susceptible reaction was characterized by tan (TAN) sporulating lesions. All known single genes have been reported ineffective when challenged with specific isolates. For instance, plant introduction (PI) 200492 (Rppl) produced an immune response when challenged with some isolates $(1,25)$, produced RB lesions to six U.S. isolates (23), and produced TAN lesions when challenged with some Asian, African, and South American isolates $(1,25,36)$.

The host differentials used to identify $P$. pachyrhizi races or pathotypes have varied, but most studies have included some or all of the existing resistance genes (Rppl to -5); however, race or pathotype nomenclature for $P$. pachyrhizi has not been standardized. In this study, we propose the use of a standard host differen- 
tial set to (i) classify the pathogenic variation in $P$. pachyrhizi isolates collected from U.S. soybean and kudzu and (ii) determine the spatial and temporal associations thereof.

\section{Materials and Methods}

Isolate collection. In total, 72 isolates of P. pachyrhizi were cultured on detached soybean leaves. These isolates were collected from infected leaf samples of soybean (46 sites) and kudzu (26 sites) in 2006 to 2009 from 12 states located in three regions: Midwest, South, and Southeast (15). Half the of isolates (50\%) were collected from the South region, while 36 and $14 \%$ were from the Southeast and Central regions, respectively. Almost half of the isolates were collected in 2008 (Table 1).

To establish cultures of $P$. pachyrhizi, two to six soybean or kudzu leaf samples were used to harvest urediniospores ( 0.5 to 2 $\mathrm{mg}$ ) from each location. These spores were used to inoculate the abaxial surface of 'Williams 82' leaf sections. When sporulation occurred, 10 to 13 days after inoculation, single-spore isolates were obtained as previously described (32). To increase inoculum, isolates were multiplied on detached leaves of Williams 82 to produce adequate amounts of spores for the experiments. Freshly harvested spores were used for all the inoculations.

Host differentials and pathogenic variation. Soybean genotypes used as host differentials were selected based on prior knowledge of their reaction to $P$. pachyrhizi. The set of eight genotypes were as follows: six lines with characterized resistance genes (3,7,13,14,19), including PI 200492 (Rppl), PI 230970 (Rpp2), PI 462312 (Rpp3), PI 506764 (Rpp3-Hyuuga), PI 459025B (Rpp4), and PI 200526 (Rpp5); UG-5, resistant but genes not characterized
$(23,33)$; and Williams 82 , a susceptible cultivar with no known resistance genes.

A detached-leaf technique was used to evaluate genotypes for their reaction to the isolates (32). Plants of each of the eight genotypes were planted every 2 weeks and placed inside a growth chamber (Percival Scientific, Inc., Boone, IA) maintained at 65 to $75 \%$ relative humidity with a cycle of $14 \mathrm{~h}$ of light $\left(500 \mu \mathrm{mol} \mathrm{m} \mathrm{m}^{-2}\right.$ $\mathrm{s}^{-1} \mathrm{PAR}$ ) and $10 \mathrm{~h}$ of darkness at 24 and $20^{\circ} \mathrm{C}$, respectively, for a constant supply of 2- to 3-week-old rust-free leaves. Excised leaflets from plants in the chamber were rinsed in three changes of sterile distilled water and their abaxial surface was sprayed with a spore suspension of $150 \mu \mathrm{l}\left(1 \times 10^{5}\right.$ spores/ml of water $)$ using an atomizer attached to an air compressor. Inoculated leaf sections (approximately 2 by $4 \mathrm{~cm}$ each) for eight differential hosts were carefully placed adaxial side down in glass petri dishes $140 \mathrm{~mm}$ in diameter by $20 \mathrm{~mm}$ on 150-mm-diameter filter papers (Whatman International Ltd., Kent, England). Sterile filter papers (two per dish) were saturated with sterile distilled water (approximately 5 $\mathrm{ml} /$ dish) prior to placing leaf sections in dishes. Additional sterile distilled water $(4 \mathrm{ml} / \mathrm{dish}$ ) was added at 10 -day intervals to keep the filter papers saturated. Petri dishes with leaf sections were incubated in the dark for a period of $12 \mathrm{~h}$ followed by a cycle of 14 $\mathrm{h}$ of light $\left(380 \mu \mathrm{mol} \mathrm{m} \mathrm{m}^{-2} \mathrm{~s}^{-1}\right)$ and $10 \mathrm{~h}$ of darkness inside a tissue chamber (Percival Scientific, Inc.) maintained at $23^{\circ} \mathrm{C}$. Prior to incubation, dishes were placed inside zip bags (Webster Industries, Peabody, MA).

Seventeen days after inoculation, the infection type was recorded as (i) type 0 , immune reaction, no visible infection; (ii) type $\mathrm{RB}$, resistant reaction, red-brown lesions with either no uredinia or

Table 1. Isolate name, host, and location of origin and year of collection of Phakopsora pachyrhizi isolates used in this study

\begin{tabular}{|c|c|c|c|c|c|}
\hline Isolate $^{\mathrm{a}}$ & Host & County & State $^{b}$ & Regionc $^{c}$ & Year \\
\hline AL07-1 & Soybean & Baldwin & Alabama & South & 2007 \\
\hline AL07-2 & Soybean & Baldwin & Alabama & South & 2007 \\
\hline AL08-1 & Kudzu & Mobile & Alabama & South & 2008 \\
\hline AL08-2 & Kudzu & Mobile & Alabama & South & 2008 \\
\hline AL08-3 & Soybean & Baldwin & Alabama & South & 2008 \\
\hline AL08-4 & Soybean & Baldwin & Alabama & South & 2008 \\
\hline AR06-1 & Soybean & Lonoke & Arkansas & South & 2006 \\
\hline AR08-1 & Soybean & Crawford & Arkansas & South & 2008 \\
\hline AR08-3 & Soybean & Crawford & Arkansas & South & 2008 \\
\hline AR08-4 & Kudzu & Garland & Arkansas & South & 2008 \\
\hline AR08-5 & Soybean & Pulaski & Arkansas & South & 2008 \\
\hline AR08-6 & Kudzu & Saline & Arkansas & South & 2008 \\
\hline AR08-7 & Soybean & Clark & Arkansas & South & 2008 \\
\hline AR08-8 & Kudzu & Union & Arkansas & South & 2008 \\
\hline AR08-9 & Soybean & Lonoke & Arkansas & South & 2008 \\
\hline AR08-10 & Soybean & White & Arkansas & South & 2008 \\
\hline AR08-14 & Soybean & Poinsett & Arkansas & South & 2008 \\
\hline AR08-15 & Soybean & Craighead & Arkansas & South & 2008 \\
\hline AR08-16 & Soybean & Lawrence & Arkansas & South & 2008 \\
\hline AR08-17 & Soybean & Greene & Arkansas & South & 2008 \\
\hline AR08-18 & Soybean & Randolph & Arkansas & South & 2008 \\
\hline AR08-19 & Soybean & Clay & Arkansas & South & 2008 \\
\hline AR08-20 & Soybean & Mississippi & Arkansas & South & 2008 \\
\hline AR08-21 & Soybean & Drew & Arkansas & South & 2008 \\
\hline FL07-1 & Soybean & Gadsden & Florida & Southeast & 2007 \\
\hline FL07-2 & Kudzu & Hernando & Florida & Southeast & 2007 \\
\hline FL07-3 & Kudzu & Hernando & Florida & Southeast & 2007 \\
\hline FL07-4 & Kudzu & Alachua & Florida & Southeast & 2007 \\
\hline FL07-5 & Kudzu & Hernando & Florida & Southeast & 2007 \\
\hline FL07-6 & Kudzu & Pasco & Florida & Southeast & 2007 \\
\hline FL07-8 & Kudzu & Alachua & Florida & Southeast & 2007 \\
\hline FL07-9 & Kudzu & Hernando & Florida & Southeast & 2007 \\
\hline FL07-10 & Kudzu & Hernando & Florida & Southeast & 2007 \\
\hline
\end{tabular}

\footnotetext{
${ }^{a}$ Isolate name with three parts: (i) state of origin (AL = Alabama, AR = Arkansas, FL = Florida, IL = Illinois, LA = Louisiana, MS = Mississippi, NC = North Carolina, OK = Oklahoma, SC = South Carolina, TX = Texas, and VA = Virginia); (ii) year of collection (2006 [06] to 2009 [09]); and (iii) isolate number within location.

b The following people contributed infected leaves: T. Allen, C. Bradley, C. Coder, J. Damicona, D. Hershman, J. Mueller, R. Hines, T. Isakeit, W. Jurick II, J. Marois, S. Monfort, B. Moore, P. Phipps, J. Rupe, R. Schneider, E. Sikora, J. Stickland, G. Upchurch, D. Walker, and A. Wrather.

${ }^{c}$ Regions were established from U.S. climate regions, the National Climatic Data Center maps (15).
} 
only sparsely sporulating uredinia; or (iii) type TAN, susceptible reaction, tan lesions usually with many uredinia and abundant sporulation (4). The number of sporulating uredinia in a randomly selected $1-\mathrm{cm}^{2}$ leaf tissue was recorded for each isolate on each differential. Inoculations with all isolates on eight genotypes were repeated once with three replications per each run, and counts recorded on each of the $1-\mathrm{cm}^{2}$ leaf sample site was one replication.

Pathotype evaluation. Infection types were recorded from differential hosts for each isolate and used to assign pathotypes for all isolates. The pathotype designation method was an octal nomenclature system proposed in the 1970s $(9,11)$ and modified in 1990 (10). Type 0 and RB were assigned as a resistant reaction (coded as 0 ) while TAN represented a susceptible reaction (coded as 1). Differentials were arranged in a fixed linear order starting with the first reported gene (Rppl) on the left. A single octal digit (0 to 7) designated the host-pathogen interaction for every set of three genotypes from left to right on the differential set (Table 2). Soybean host differentials were grouped as follows: $R p p 1, R p p 2$, and $R p p 3$, the first digit; Rpp3-Hyuuga, Rpp4, and Rpp5, the second digit; and UG-5 and Williams, the third digit.

Aggressiveness evaluation. The aggressiveness among isolates was evaluated using the number of uredinia per square centimeter of leaf tissue. Prior to analysis, the number of uredinia per square centimeter of leaf tissue from both runs was tested for homogeneity of error variance by analysis of variance in PROC GLM of SAS (version 9.1.3; SAS Institute Inc., Cary, NC). Because no heterogeneity was detected, data were pooled over runs for final analysis and presentation. Averaged totals of sporulating uredinia per square centimeter over replications and runs recorded on the differential set for each isolate were subjected to preliminary analysis using PROC UNIVARIATE in SAS to examine the distribution of sporu- lating uredinia per square centimeter of leaf tissue. From this analysis, three classes of sporulating uredinia were defined (low, medium, and high) based on the departure from the grand mean for number of sporulating uredinia across all isolates and genotypes. These classes consisted of sporulating uredinia numbers that were less than one standard deviation below the grand mean (low), plus or minus one standard deviation from the grand mean (medium), and greater than one standard deviation above the grand mean (high).

Table 2. Octal code to combinations of infection types in a binary code (resistant: no visible infection or red-brown lesions, and susceptible: tan sporulating lesions; coded as 0 and 1 , respectively) in a triplet of differential soybean genotypes $(\mathrm{A}, \mathrm{B} \text {, and } \mathrm{C})^{\mathrm{a}}$

\begin{tabular}{lcccc}
\hline & \multicolumn{3}{c}{ Genotypes } & \\
\cline { 2 - 4 } Reactions $^{\mathbf{b}}$ & $\mathbf{A}$ & $\mathbf{B}$ & $\mathbf{C}$ & Octal digit \\
\hline None & 0 & 0 & 0 & 0 \\
One & 0 & 0 & 1 & 1 \\
& 0 & 1 & 0 & 2 \\
Two & 1 & 0 & 0 & 3 \\
& 0 & 1 & 1 & 4 \\
Three & 1 & 0 & 1 & 5 \\
& 1 & 1 & 0 & 6 \\
\hline
\end{tabular}

${ }^{a}$ In case differentials do not make a triplet, the addition of a differential with a nonsusceptible reaction (binary code 0 ) is represented by octal digit 0 while the susceptible reaction (binary code 1 ) is represented by octal digit 1 . For the addition of two differentials, binary codes of 00,01 , 10 , and 11 are represented by octal digits $0,1,2$, and 4 , respectively. Adopted from Goodwin et al. (10).

${ }^{\mathrm{b}}$ Susceptible reaction per triplet.

Table 1. (continued from preceding page)

\begin{tabular}{|c|c|c|c|c|c|}
\hline Isolate $^{a}$ & Host & County & State $^{\mathrm{b}}$ & Region $^{\mathrm{c}}$ & Year \\
\hline FL07-13 & Kudzu & Marion & Florida & Southeast & 2007 \\
\hline FL09-1 & Kudzu & Taylor & Florida & Southeast & 2009 \\
\hline FL09-2 & Kudzu & Taylor & Florida & Southeast & 2009 \\
\hline FL09-3 & Kudzu & Taylor & Florida & Southeast & 2009 \\
\hline FL09-4 & Kudzu & Jefferson & Florida & Southeast & 2009 \\
\hline FL09-5 & Kudzu & Jefferson & Florida & Southeast & 2009 \\
\hline GA08-1 & Kudzu & Baxley & Georgia & Southeast & 2008 \\
\hline GA08-2 & Kudzu & Waycross & Georgia & Southeast & 2008 \\
\hline IL06-1 & Soybean & Jefferson & Illinois & Central & 2006 \\
\hline IL07-1 & Soybean & Jefferson & Illinois & Central & 2007 \\
\hline IL08-1 & Soybean & McLean & Illinois & Central & 2008 \\
\hline IL08-2 & Soybean & Union & Illinois & Central & 2008 \\
\hline IL08-3 & Soybean & Jackson & Illinois & Central & 2008 \\
\hline IL08-4 & Soybean & Marshall & Illinois & Central & 2008 \\
\hline IL08-5 & Soybean & Madison & Illinois & Central & 2008 \\
\hline IL09-1 & Soybean & Pulaski & Illinois & Central & 2009 \\
\hline IL09-2 & Soybean & Saline & Illinois & Central & 2009 \\
\hline IL09-3 & Soybean & Saline & Illinois & Central & 2009 \\
\hline LA08-1 & Soybean & E Baton Rouge & Louisiana & South & 2008 \\
\hline LA08-2 & Soybean & E Baton Rouge & Louisiana & South & 2008 \\
\hline LA08-3 & Soybean & E Baton Rouge & Louisiana & South & 2008 \\
\hline LA09-1 & Soybean & Bossier & Louisiana & South & 2009 \\
\hline MS06-1 & Kudzu & Jefferson & Mississippi & South & 2006 \\
\hline MS06-2 & Soybean & Warren & Mississippi & South & 2006 \\
\hline MS07-1 & Soybean & Humphreys & Mississippi & South & 2007 \\
\hline MS07-3 & Soybean & Warren & Mississippi & South & 2007 \\
\hline MS07-4 & Soybean & Washington & Mississippi & South & 2007 \\
\hline NC07-1 & Soybean & Lenoir & North Carolina & Southeast & 2007 \\
\hline OK07-1 & Soybean & Tulsa & Oklahoma & Southeast & 2007 \\
\hline SC06-1 & Kudzu & Calhoun & South Carolina & Southeast & 2006 \\
\hline TX07-1 & Soybean & Hidalgo & Texas & South & 2007 \\
\hline TX07-2 & Soybean & Hidalgo & Texas & South & 2007 \\
\hline TX07-3 & Soybean & Cameron & Texas & South & 2007 \\
\hline TX07-6 & Soybean & Hidalgo & Texas & South & 2007 \\
\hline TX08-1 & Kudzu & Liberty & Texas & South & 2008 \\
\hline TX08-2 & Soybean & Hidalgo & Texas & South & 2008 \\
\hline TX08-3 & Kudzu & Liberty & Texas & South & 2008 \\
\hline TX09-1 & Kudzu & Livingston & Texas & South & 2009 \\
\hline VA07-1 & Soybean & Chesapeake & Virginia & Southeast & 2007 \\
\hline
\end{tabular}


The three classes of sporulating uredinia were used to examine the multivariate structure of $P$. pachyrhizi isolates by principal component analysis as previously described $(8,34)$ using SAS.

Isolate diversity by zone, year, and host. Shannon's index (30) was used to estimate pathogen diversity in the different geographical locations, years (2006 to 2009), and hosts (soybean and kudzu). The index was calculated using the formula $H(A)=-\Sigma[(n i / N) \times$ $\ln (n i / N)]$, where $n i$ is the number of $P$. pachyrhizi genotypes in the $i$ th race or pathotype group and $N$ is the total number of $P$. pachyrhizi genotypes in the population.

\section{Results}

Isolate pathotypes. Interactions between $P$. pachyrhizi isolates and the set of differentials produced three infection types. Inoculation on the resistant genotype UG-5 resulted in infection type 0

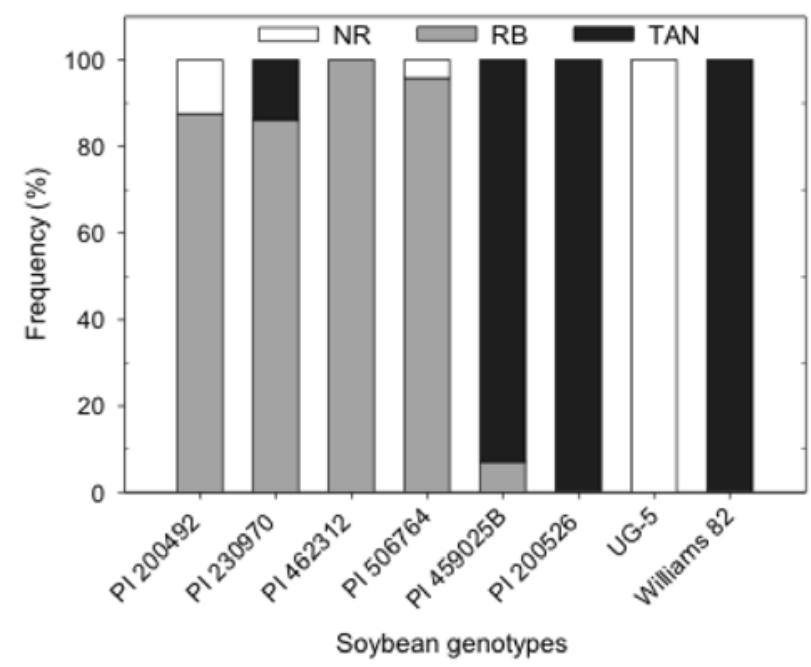

Fig. 1. Frequency of infection types on a set of eight soybean differentials inoculated with 72 Phakopsora pachyrhizi isolates collected in the United States. NR: type 0 (no visible infection or no reaction), RB: red-brown, and TAN: tan reaction. (immune or no visible reaction) for all 72 P. pachyrhizi isolates. All isolates produced an RB lesion type on PI 462312 (Rpp3) and a TAN lesion type on PI 200526 (Rpp5) and Williams 82. Infection types on PI 200492 (Rppl) and PI 506764 (Rpp3-Hyuuga) included an RB lesion type produced by 87 and $95 \%$ of the isolates, respectively, on both genotypes and no reaction produced by the rest of isolates. Similarly, 86 and $7 \%$ of isolates produced an RB lesion type and 14 and 93\% produced TAN on PI 230970 (Rpp2) and PI 459025B (Rpp4), respectively (Fig. 1).

Based on the resistant (type 0 or RB) and susceptible (TAN) reactions of the 72 U.S. P. pachyrhizi isolates on the eight differentials, three pathotypes coded as 011, 041, and 241 accounted for 5, 57 , and 10 isolates, respectively (Table 3 ). Pathotype 241 was the most virulent group because isolates in this group produced the susceptible TAN reaction on four differentials. Pathotype 011 was the least virulent because isolates in this group produced the susceptible reaction on only two differentials (Table 3 ).

Isolate aggressiveness. Inoculation of the differentials with $P$. pachyrhizi isolates resulted in compatible reactions except for the resistant genotype UG-5 (no lesion development) and PI 200492 (Rppl, few lesions but no uredinia). PI 506764 (Rpp3-Hyuuga) had $\leq 1$ mean sporulating uredinia $/ \mathrm{cm}^{2}$ of leaf tissue except for isolates in aggressiveness group 6 (Table 4). For the other genotypes, mean sporulating uredinia counts ranged from 1 to 32 uredinia $/ \mathrm{cm}^{2}$ of leaf tissue. The average number of sporulating uredinia per square centimeter of leaf area for all RB and TAN lesion types recorded for all isolates were $2.4 \pm 4$ (standard deviation) and $17 \pm 10$, respectively.

Six unique aggressiveness groups were established based on the three classes of sporulating uredinia observed on the differentials. Isolates in group 6 were the most aggressive and had the highest numbers of uredinia per square centimeter of leaf area from differentials on which sporulation was observed. Isolates in group 1 were the least aggressive (Table 4).

Isolate diversity by region, year, and host. All three pathotypes were found among the isolates collected from the South region while only two pathotypes were observed in samples from the Central (011 and 041) and the Southeast (041 and 241) regions (Fig. 2A1). All pathotypes were observed in isolates

Table 3. Pathotypes of Phakopsora pachyrhizi isolates collected in the United States based on the resistant (-) or susceptible (+) reaction on soybean differentials $^{\mathrm{a}}$

\begin{tabular}{|c|c|c|c|c|c|c|c|c|c|}
\hline \multirow[b]{2}{*}{ Pathotypes } & \multirow[b]{2}{*}{$\begin{array}{l}\text { Number of } \\
\text { isolates }\end{array}$} & \multicolumn{8}{|c|}{ Differentials } \\
\hline & & $\begin{array}{l}\text { PI } 200492 \\
\text { (RppI) }\end{array}$ & $\begin{array}{c}\text { PI 230970 } \\
\text { (Rpp2) }\end{array}$ & $\begin{array}{c}\text { PI } 462312 \\
\text { (Rpp3) }\end{array}$ & $\begin{array}{c}\text { PI 506764 } \\
\text { (Rpp3-Hyuuga) }\end{array}$ & $\begin{array}{l}\text { PI 459025B } \\
\text { (Rpp4) }\end{array}$ & $\begin{array}{l}\text { PI } 200526 \\
\text { (Rpp5) }\end{array}$ & UG-5 & $\begin{array}{c}\text { Williams } \\
82\end{array}$ \\
\hline 011 & 5 & - & - & - & - & - & + & - & + \\
\hline 041 & 57 & - & - & - & - & + & + & - & + \\
\hline 241 & 10 & - & + & - & - & + & + & - & + \\
\hline
\end{tabular}

${ }^{a}$ Pathotypes 011, 041, and 241 were established based on the resistant (no visible infection or red-brown lesions) and susceptible (tan sporulating lesions) reactions on differentials and were coded based on a modified octal nomenclature system (10).

Table 4. Aggressiveness groups with mean and standard deviation of sporulating uredinia on a set of eight differential genotypes of soybean for 72 Phakopsora pachyrhizi isolates collected in the United States from 2006 to 2009

\begin{tabular}{|c|c|c|c|c|c|c|c|c|c|}
\hline \multirow[b]{2}{*}{ Groups $^{\mathbf{a}}$} & \multirow[b]{2}{*}{$\begin{array}{c}\text { Number of } \\
\text { isolates }^{\mathbf{b}}\end{array}$} & \multicolumn{8}{|c|}{ Uredinia per square centimeter of leaf tissue } \\
\hline & & $\begin{array}{c}\text { PI } 200492 \\
(\text { Rpp } 1) \\
\end{array}$ & $\begin{array}{c}\text { PI 230970 } \\
(\text { Rpp2) } \\
\end{array}$ & $\begin{array}{l}\text { PI 462312 } \\
\text { (Rpp3) }\end{array}$ & $\begin{array}{c}\text { PI 506764 } \\
\text { (Rpp3-Hyuuga) } \\
\end{array}$ & $\begin{array}{c}\text { PI 459025B } \\
(\text { Rpp4) }\end{array}$ & $\begin{array}{c}\text { PI 200526 } \\
\text { (Rpp5) }\end{array}$ & UG-5 & $\begin{array}{c}\text { Williams } \\
82 \\
\end{array}$ \\
\hline 1 & 8 & 0.0 & $0.7 \pm 0.4$ & $4.0 \pm 3.6$ & 0.0 & $8.1 \pm 3.7$ & $6.6 \pm 2.2$ & 0.0 & $14.3 \pm 2.0$ \\
\hline 2 & 8 & 0.0 & $3.0 \pm 2.3$ & $9.1 \pm 3.2$ & 0.0 & $18.1 \pm 4.8$ & $11.8 \pm 3.8$ & 0.0 & $27.9 \pm 6.3$ \\
\hline 3 & 37 & 0.0 & $1.6 \pm 1.6$ & $5.7 \pm 2.0$ & 0.0 & $10.8 \pm 3.0$ & $10.5 \pm 2.3$ & 0.0 & $24.0 \pm 3.6$ \\
\hline 4 & 8 & 0.0 & $2.0 \pm 1.7$ & $6.1 \pm 2.6$ & $0.7 \pm 0.3$ & $10.8 \pm 2.4$ & $12.3 \pm 3.2$ & 0.0 & $27.3 \pm 5.7$ \\
\hline 5 & 5 & 0.0 & $5.3 \pm 5.7$ & $8.9 \pm 5.7$ & 0.0 & $14.2 \pm 5.8$ & $18.1 \pm 2.2$ & 0.0 & $28.5 \pm 9.1$ \\
\hline 6 & 6 & 0.0 & $3.1 \pm 1.2$ & $8.7 \pm 4.8$ & $4.8 \pm 1.4$ & $13.0 \pm 3.3$ & $20.0 \pm 1.1$ & 0.0 & $31.7 \pm 4.8$ \\
\hline
\end{tabular}

a Three classes of sporulating uredinia obtained by the PROC UNIVARIATE analysis in SAS based on the distribution of overall mean averaged over isolates and differentials were used to assign isolates into aggressiveness groups. The three classes were low, medium, and high, and consisted of sporulating uredinia numbers that were less than one standard deviation below the grand mean, plus or minus one standard deviation from the grand mean, and greater than one standard deviation above the grand mean respectively. The groups of $P$. pachyrhizi isolates were developed by principal component analysis using SAS with uredinia classes $(1,2$, or 3$)$ on each host differential regarded as variables and each isolate was regarded as an observation (34).

${ }^{b}$ Number of isolates in each aggressiveness group. 
collected in 2008, whereas only two pathotypes were observed in both 2007 and 2009 (Fig. 2A2) and only pathotype 041 was found among isolates collected in 2006. All pathotypes were found among isolates established from kudzu as well as from soybean (Fig. 2A3).

All six aggressiveness groups were found among isolates collected from the South region, while only three and four groups were observed on isolates from the Central and Southeast regions, respectively (Fig. 2B1). All six aggressiveness groups also occurred among isolates collected in 2008, while four, three, and two
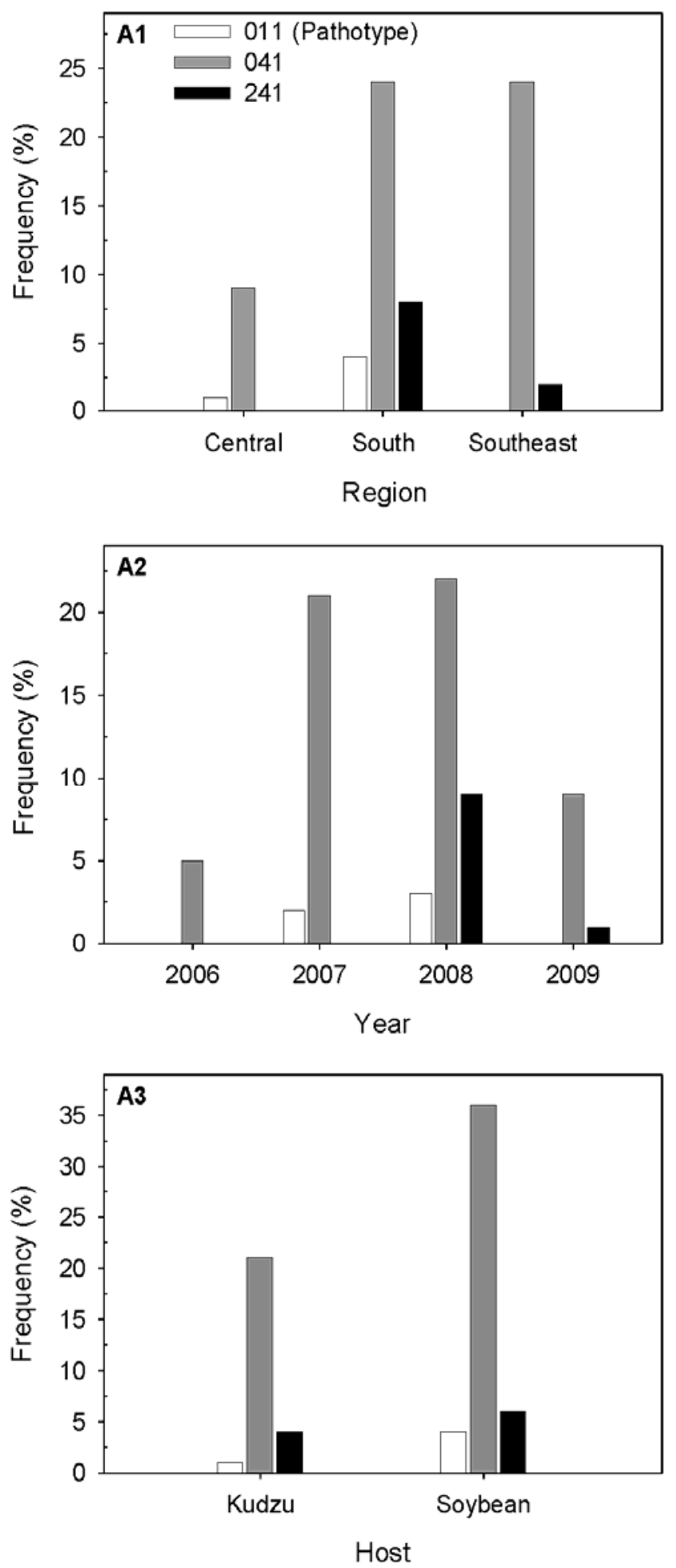

groups were collected in 2007, 2006, and 2009, respectively (Fig. 2B2). All six aggressiveness groups were found in isolates obtained from either kudzu or soybean (Fig. 2B3).

All six aggressiveness groups occurred within pathotype 041 . Isolates in aggressiveness group 1 were not found in pathotype 241 and only isolates in aggressiveness groups 3 and 4 were part of pathotype 011 (Fig. 3).

No state had all three pathotypes but five states had two pathotypes (Table 5). The state of Arkansas was the only state to have all six aggressiveness groups (Table 5).
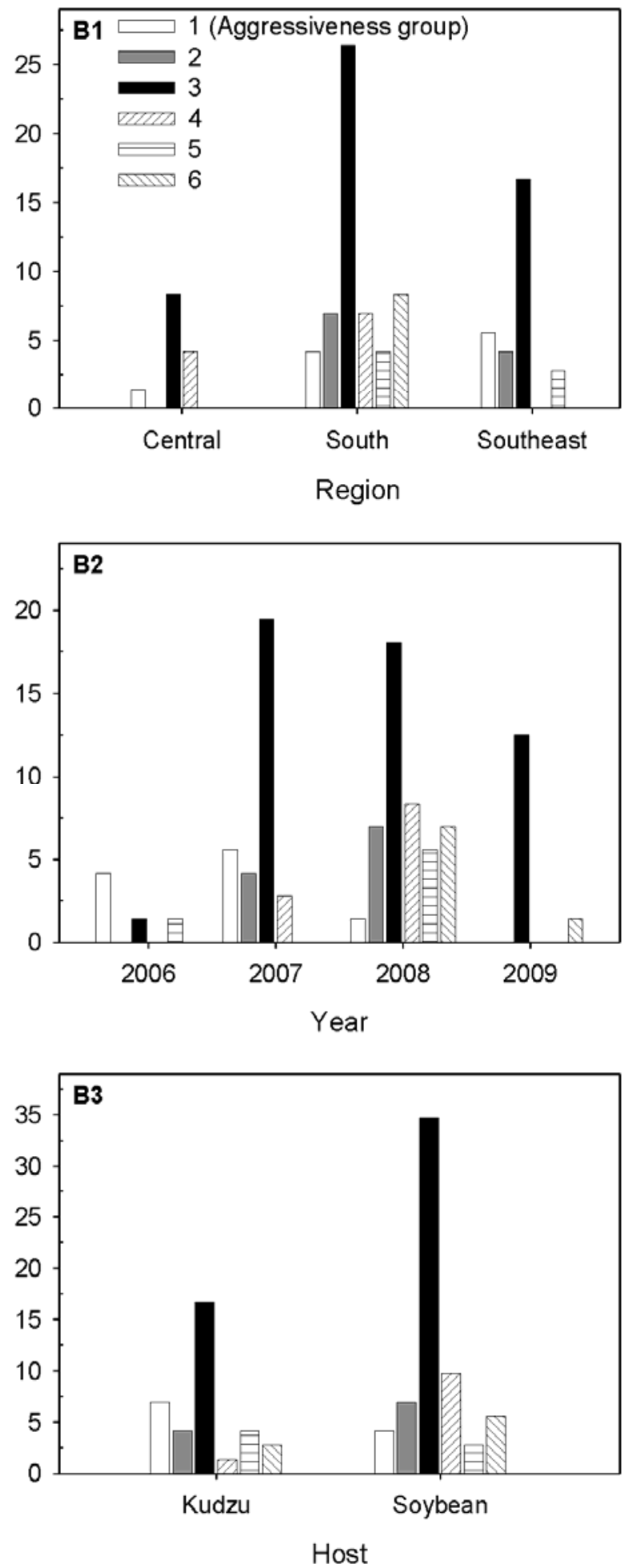

Fig. 2. Frequency of A, pathotypes and B, aggressiveness groups of 72 Phakopsora pachyrhizi isolates collected in the United States by region (A1 and B1), year (A2 and $\mathrm{B} 2)$, and host (A3 and B3). 
Shannon's index for diversity $(\mathrm{H})$ calculated on the number of pathotypes revealed a more diverse $P$. pachyrhizi population in the South $(H=0.83)$ compared with the population in other regions (Table 6). The highest $H$ value was observed on $P$. pachyrhizi isolates collected in 2008. However, little difference in Shannon's index was observed between isolates established from either kudzu or soybean ( $H=0.60$ and 0.70 , respectively). This was due to the presence of all three pathotypes on isolates obtained from kudzu or soybean.

\section{Discussion}

The introduction of P. pachyrhizi to the continental United States is relatively recent (28). Our collection of $P$. pachyrhizi isolates began in 2006 after the disease was found in Illinois (12), a precondition for acquisition of an Animal and Plant Health Inspection Service permit to work with the fungus in that state. Our results from this short collection period indicate that the population of $P$. pachyrhizi is diverse, because three pathotypes and six aggressiveness groups were described. The creation of pathotype and aggressiveness groups provides a snapshot of $P$. pachyrhizi isolate variation in the United States for the collection period, and will serve as the foundation for comparing isolates characterized in the future.

Host specialization of plant pathogens within areas, countries, or continents has been of interest for many years and has been especially well documented for some plant pathogens (e.g., wheat rust; 16,20). The first known host specialization study on P. pachyrhizi populations was reported in 1966 when different hosts were shown to have variable lesion types when inoculated with the same isolates collected from Taiwan (17). Further interest came after the first known resistance gene, Rppl, was shown to be ineffective on

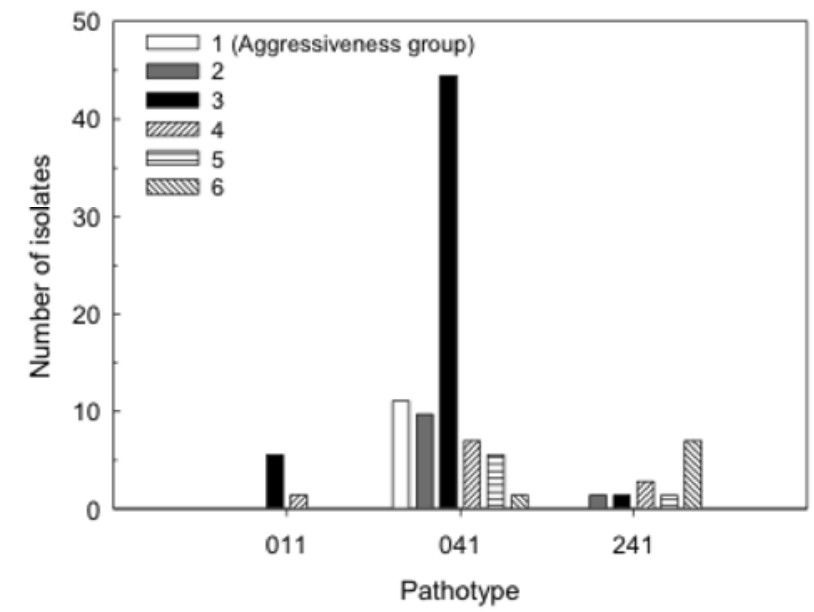

Fig. 3. Number of Phakopsora pachyrhizi isolates in six aggressiveness groups grouped by pathotype $(011,041$, and 241$)$. isolates collected from Australia (18). In our study, we reported three virulence phenotypes in $P$. pachyrhizi isolates collected from the United States and, based on the six differentials with resistance genes, there could be many virulence phenotypes. Based on the literature, some of these other phenotypes are known to exist in $P$. pachyrhizi isolates in Africa, Asia, Australia, and South America $(1,25,31,36-38)$. Moreover, as new host resistance genes are discovered, more phenotypes will inevitably be described. In our study, we adopted the modified octal nomenclature system (10) for pathotype designation of $P$. pachyrhizi isolates. This method has advantages that include (i) easy accommodation of additional differentials by adding them to the right of those currently used and (ii) the ability to easily compare virulence phenotypes described by others.

With the recent introduction of $P$. pachyrhizi to the continental United States, it appears that populations may be altered based on survival on kudzu through the winter. Although sample sizes are somewhat limited, there seemed to be more variation in virulence of isolates that were collected in the continental United States in 2004 than in following years. Isolates collected in 2004 were reported to overcome Rppl resistance causing TAN lesions $(1,25)$, whereas later U.S. collections (23) and those included in our current study appear not to cause a susceptible reaction on sources of resistance with Rppl. Furthermore, a differential response on PI 462312 (Rpp3) and an RB reaction on PI 459025B (Rpp4) produced by isolates collected in 2004 (25) was not observed in our study because all isolates produced an $\mathrm{RB}$ and TAN reaction on PI 462312 (Rpp3) and PI 459025B (Rpp4), respectively.

Following the introduction of $P$. pachyrhizi into the continental United States, the overwintering geographic distribution of the pathogen has been limited to frost-free areas where patches of kudzu in the southern states along the Gulf of Mexico survive, resulting in a potential reduction of diversity that may have come with the first introduction in 2004. In addition, and in contrast to soybean, the RB reaction is common on kudzu (2). In nature, those isolates that produce an RB reaction on kudzu may have limited sporulation and less overwintering survival capacity than other isolates. In the last few years, $P$. pachyrhizi has been reported in Cuba and Mexico $(24,27)$. Although the pathotypes and aggressiveness groups are unknown in these regions, it is likely that further variability in the population may be observed in the continental United States from offshore introductions. For this reason, it is important to monitor the population dynamics of $P$. pachyrhizi at regular intervals. This will become increasingly important once resistance genes are deployed in the southern growing region.

Virulence patterns on a differential set explain the existence of different races or pathotypes among isolates. Comparisons between virulence phenotypes of isolates identified in different places or countries also can be made through the use of a standard set of differentials. Most pathogenic variation studies on $P$. pachyrhizi isolates have focused on the use of soybean genotypes as differentials; however, in a few cases, soybean and other legume acces-

Table 5. Number of isolates $(N)$ in each pathotype and aggressiveness group for each of the 12 U.S. states where isolates of Phakopsora pachyrhizi were collected

\begin{tabular}{|c|c|c|c|c|c|c|c|c|c|c|}
\hline \multirow[b]{2}{*}{ State } & \multirow[b]{2}{*}{$N$} & \multicolumn{3}{|c|}{ Pathotype } & \multicolumn{6}{|c|}{ Aggressiveness group } \\
\hline & & 011 & 041 & 241 & 1 & 2 & 3 & 4 & 5 & 6 \\
\hline Alabama & 6 & 0 & 4 & 2 & 0 & 0 & 2 & 1 & 2 & 1 \\
\hline Arkansas & 18 & 0 & 13 & 5 & 1 & 3 & 9 & 2 & 1 & 2 \\
\hline Florida & 15 & 0 & 15 & 0 & 3 & 1 & 11 & 0 & 0 & 0 \\
\hline Georgia & 2 & 0 & 2 & 0 & 0 & 1 & 0 & 0 & 1 & 0 \\
\hline Illinois & 10 & 1 & 9 & 0 & 1 & 0 & 6 & 3 & 0 & 0 \\
\hline Louisiana & 4 & 0 & 1 & 3 & 0 & 0 & 1 & 0 & 0 & 3 \\
\hline Mississippi & 5 & 0 & 5 & 0 & 2 & 1 & 2 & 0 & 0 & 0 \\
\hline North Carolina & 1 & 0 & 1 & 0 & 1 & 0 & 0 & 0 & 0 & 0 \\
\hline Oklahoma & 1 & 0 & 1 & 0 & 0 & 0 & 1 & 0 & 0 & 0 \\
\hline South Carolina & 1 & 0 & 1 & 0 & 0 & 0 & 0 & 0 & 1 & 0 \\
\hline Texas & 8 & 4 & 4 & 0 & 0 & 1 & 5 & 2 & 0 & 0 \\
\hline Virginia & 1 & 0 & 1 & 0 & 0 & 1 & 0 & 0 & 0 & 0 \\
\hline
\end{tabular}


Table 6. Shannon's index $(H)$ for diversity among Phakopsora pachyrhizi population (based on pathotype) by region, year, and host

\begin{tabular}{lcll}
\hline Attribute & $\begin{array}{c}\text { Number of } \\
\text { isolates }\end{array}$ & $\begin{array}{c}\text { Number of } \\
\text { pathotypes }^{\mathbf{a}}\end{array}$ & $\boldsymbol{H}$ \\
\hline Region & & & \\
Central & 10 & $2(011,041)$ & 0.23 \\
$\quad$ South & 38 & 3 & 0.83 \\
$\quad$ Southeast & 24 & $2(041,241)$ & 0.34 \\
Year & & & \\
2006 & 5 & $2(041)$ & 0 \\
2007 & 23 & 3 & 0.30 \\
2008 & 34 & $2(041,041)$ & 0.63 \\
2009 & 10 & 3 & 0.33 \\
Host & & 3 & 0.60 \\
Kudzu & 26 & $461)$ & 0.70 \\
Soybean & 46 &
\end{tabular}

${ }^{a}$ Number of pathotypes found in the group of isolates (the three pathotypes are 011, 041, and 241). Names of pathotypes were added in parentheses whenever only one or two were found.

sions (17) and other Glycine spp. (6) were used. Ideally, a host differential set should be more universal and consist of isolines of characterized genes for resistance. For this reason, the genotypes assembled for this study included six soybean genotypes with the known resistance genes ( $R p p)$, with the intention of adding other resistant genotypes in the future as they are identified and characterized. Furthermore, the nomenclature system used in our study allows easy comparisons of isolates from different locations and may prove useful in comparing future studies of pathogenic variation of $P$. pachyrhizi populations.

Information on the qualitative nature of virulence based on resistant (immune or RB) and susceptible (TAN) reactions, as well as information on the quantitative nature of uredinia production, may be useful in strategies for the deployment of new sources of resistance. Future research efforts should focus on identifying pathogenic variation in different regions close to the United States such as Mexico, Cuba, and some Caribbean islands. This information may be used to identify soybean genotypes with specific resistance to prevailing pathotype groups in respective regions, especially in cases where countries are deploying resistance genes to manage soybean rust.

\section{Acknowledgments}

We thank the United Soybean Board for partial financial support of this research, R. L. Nelson and his staff (United States Department of Agriculture Soybean Germplasm Collection Center, Urbana, IL.) for providing soybean seed used in this study, T. Herman for her editorial inputs, and others associated with researchers listed in Table 1 who assisted in providing infected leaf material.

\section{Literature Cited}

1. Bonde, M. R., Nester, S. E., Austin, C. N., Stone, C. L., Frederick, R. D., Hartman, G. L., and Miles, M. R. 2006. Evaluation of virulence of Phakopsora pachyrhizi and P. meibomiae isolates. Plant Dis. 90:708-716.

2. Bonde, M. R., Nester, S. E., Morre, W. F., and Allen, T. W. 2009. Comparative susceptibility of kudzu accessions from the southeastern United States to infection by Phakopsora pachyrhizi. Plant Dis. 93:593-598.

3. Bromfield, K. R., and Hartwig, E. E. 1980. Resistance to soybean rust (Phakopsora pachyrhizi) and mode of inheritance. Crop Sci. 20:254-255.

4. Bromfield, K. R., Melching, J. S., and Kingsolver, C. H. 1980. Virulence and aggressiveness of Phakopsora pachyrhizi isolates causing soybean rust. Phytopathology 70:17-21.

5. Burdon, J. J., and Lenne, J. 1989. The Phakopsora pachyrhizi-Kennedia rubicunda host-pathogen association and its relation to leaf rust of Glycine spp. Aust. J. Agric. Res. 40:265-272.

6. Burdon, J. J., and Speer, S. S. 1984. A set of differential Glycine hosts for the identification of races of Phakopsora pachyrhizi Syd. Euphytica 33:891896.

7. Calvo, E. S., Kiihl, R. A. S., Garcia, A., Harada, A., and Hiromoto, D. M. 2008. Two major recessive soybean genes conferring soybean rust resistance. Crop Sci. 48:1350-1354

8. Chakraborty, S., Fernandes, C. D., Charchar, M. J. d' A., and Thomas, M. R. 2002. Pathogenic variation in Colletotrichum gloeosporioides infecting Stylosanthes spp. in a center of diversity in Brazil. Phytopathology 92:553-562.

9. Gilmour, J. 1973. Octal notation for designating physiologic races of plant pathogens. Nature 242:620.

10. Goodwin, S., Allard, R. W., and Webster, R. K. 1990. A nomenclature for Rhynchosporium secalis pathotypes. Phytopathology 80:1330-1336.

11. Habgood, R. M. 1970. Designations of physiological races of plant pathogens. Nature 227:1268-1269.

12. Hartman, G. L., Hines, R. A., Faulkner, C. D., Lynch, T. N., and Pataky, N. 2007. Late season occurrence of soybean rust caused by Phakopsora pachyrhizi on soybean in Illinois. Plant Dis. 91:466.

13. Hartwig, E. E. 1986. Identification of a 4th major gene conferring resistance to soybean rust. Crop Sci. 26:1135-1136.

14. Hartwig, E. E., and Bromfield, K. R. 1983. Relationships among three genes conferring specific resistance to rust in soybeans. Crop Sci. 23:237239.

15. Karl, T., and Koss, W. 1984. Regional and National Monthly, Seasonal and Annual Temperature Weighted by Area, 1895-1983 Hist. Climatol. Ser. 4-3, National Climatic Data Center, Ashville, NC

16. Kolmer, J. A., Long, D. L., and Hughes, M. E. 2010. Physiologic specialization of Puccinia triticina on wheat in the United States in 2008. Plant Dis. 94:775-780

17. Lin, S. Y. 1966. Studies on the physiologic races of soybean rust fungus, Phakopsora pachyrhizi Syd. J. Taiwan Agric. Res. 15:24-28.

18. McLean, R. J., and Byth, D. E. 1976. Resistance of soybean rust in Australia. Aust. Soc. Plant Pathol. Newsl. 5:34-36.

19. McLean, R. J., and Byth, D. E. 1980. Inheritance of resistance to rust (Phakopsora pachyrhizi) in soybeans. Aust. J. Agric. Res. 31:951-956.

20. Ordoñez, M., and Kolmer, J. A. 2007. Virulence phenotypes of a worldwide collection of Puccinia triticina from durum wheat. Phytopathology 97:344351.

21. Park, S., Chen, Z.-Y., Chandra, A. K., Schneider, R. W., and Hollier, C. A. 2008. Viability of Phakopsora pachyrhizi urediniospores under simulated southern Louisiana winter temperature conditions. Plant Dis. 92:1456-1462.

22. Parlevliet, J. E. 1985. Race and pathotype concepts in parasitic fungi. Bull. OEPP/EPPO Bull. 15:145-150.

23. Paul, C., and Hartman, G. L. 2009. Sources of soybean rust resistance challenged with single-spored isolates of Phakopsora pachyrhizi collected from the USA. Crop Sci. 49:1781-1785

24. Pérez Vicente, L., Martínez-de la Parte, E., Pérez-Miranda, M., MartínTriana, E., Borrás-Hidalgo, O., and Hernández-Estévez, I. 2010. First report of Asian rust of soybean caused by Phakopsora pachyrhizi in Cuba. Plant Pathol. 59:803.

25. Pham, T. A., Miles, M. R., Frederick, R. D., Hill, C. B., and Hartman, G. L. 2009. Differential responses of resistant soybean genotypes to ten isolates of Phakopsora pachyrhizi. Plant Dis. 93:224-228.

26. Ramstedt, M., Hurtado, S., and Åström, B. 2002. Pathotypes of Melampsora rust on Salix in short-rotation forestry plantations. Plant Pathol. 51:185-190.

27. Rodríguez, A., Rios, J. A., and Hernández, J. 2006. First report of Asian soybean rust caused by Phakopsora pachyrhizi from Mexico. Plant Dis. 90:1260

28. Schneider, R. W., Hollier, C. A., H. K., W., Palm, M. E., McKemy, J. M., Hernandez, J. R., Levy, L., and DeVries-Paterson, R. 2005. First report of soybean rust caused by Phakopsora pachyrhizi in the continental United States. Plant Dis. 89:774.

29. Shaner, G., Stomberg, E., Lacy, G., Barker, K., and Pirone, T. 1992. Nomenclature and concepts of pathogenicity and virulence. Annu. Rev. Phytopathol. 30:47-66.

30. Shannon, C., and Weaver, W. 1949. The Mathematical Theory of Communication. University of Illinois Press, Urbana.

31. Tan, Y. J., and Sun, Y. L. 1989. Preliminary studies on physiological races of soybean rust. Soybean Sci. (China) 8:71-74.

32. Twizeyimana, M., and Hartman, G. L. 2010. Culturing Phakopsora pachyrhizi on detached leaves and urediniospore survival at different temperatures and relative humidities. Plant Dis. 94:1453-1460.

33. Twizeyimana, M., Ojiambo, P. S., Ikotun, T., Ladipo, J. L., Hartman, G. L., and Bandyopadhyay, R. 2008. Evaluation of soybean germplasm for resistance to soybean rust (Phakopsora pachyrhizi) in Nigeria. Plant Dis. 92:947-952.

34. Twizeyimana, M., Ojiambo, P. S., Sonder, K., Ikotun, T., Hartman, G. L. and Bandyopadhyay, R. 2009. Pathogenic variation of Phakopsora pachyr hizi infecting soybean in Nigeria. Phytopathology 99:353-361.

35. USDA. 2011. Pest Information Platform for Extension and Education. Online publication. http://www.sbrusa.net.

36. Yamanaka, N., Yamaoka, Y., Kato, M., Lemos, N. G., Passianotto, A., Santos, J., Benitez, E., Abdelnoor, R., Soares, R., and Suenaga, K. 2010. Development of classification criteria for resistance to soybean rust and differences in virulence among Japanese and Brazilian rust populations. Trop. Plant Pathol. 35:153-162.

37. Yamaoka, Y., Fujiwars, Y., Kakishima, M., Katsuya, K., and Yamada, K. 2002. Pathogenic races of Phakopsora pachyrhizi on soybean and wild host plants collected in Japan. J. Gen. Plant Pathol. 68:52-56.

38. Yeh, C. C. 1983. Physiological races of Phakopsora pachyrhizi in Taiwan. J. Agric. Res. China 32:69-74. 